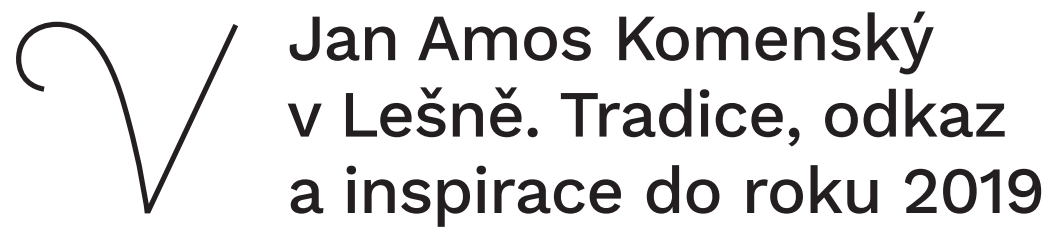

\section{Kamila Szymańska}

a Okresní muzeum v Lešně

szymanskamila68@gmail.com

DOI 10.15240/tul/006/2021-2-008
J. A. Komenský strávil v Lešně 26 let a jeho působení výrazně ovlivnilo dějiny města. Jméno tohoto geniálního pedagoga a vychovatele, duchovní ho a teologa dodnes vyvolává protichůdné reakce a kontroverzní postoje:

od uznání a respektu až po kritické, či dokonce negativní názory na jeho politickou angažovanost za polsko-švédské války. Ta dala dokonce vzniknout jeho „černélegendě“. Přesto je Komenský i nadále př́itomen jak v diskurzu o minulosti Lešna, tak v jeho městském prostoru - jako patron škol a náměstí, jako ústřední postava pomníků, výstav, publikací, vzdělávacích aktivit, a dokonce jako součást popkultury. Komenský a čeští bratři formovali kulturní a náboženskou identitu Lešna, rovněž ovlivnil také duchovní a hmotné dědictví města. ${ }^{1}$

Při vypálení Lešna v dubnu 1656 došlo ke zničení dědictví mnoha generací, včetně majetku Komenského. Dnes již nelze rekonstruovat, kde stával jeho dům. Zachoval se však kostel, ve kterém vykonával bohoslužby, kázal a shromaždoval kolem sebe věřící. Oblastní muzeum v Lešně spravuje hmotné dědictví, jež se do roku 1945 nacházelo v kostele svatého Jana - vzácné zlaté artefakty a umělecké předměty, dary zámožných šlechtických i měštanských členů farnosti. Pro

1 DWORZACZKOWA, J., 1991. Bracia czescy przejawem odrębności Wielkopolski. Przyjaciel Ludu, č. 2-3, s. 15-18; MNICH, R., 2007. Trzy recepcje Jana Amosa Komeńskiego. In: Jan Amos Komeński a kultura epoki baroku, vyd. B. Sitarska, MNICH, R., 2007. Siedlce, s. 133-142; SZYMAŃSKA, Kamila, 2012. Recepcja Jana Amosa Komeńskiego w Lesznie do 1939 roku na tle zainteresowania pedagogiem i jego twórczością w Europie Środkowej. In: Jan Amos Komeński a Europa XVII wieku. Vyd. B. Sitarska, MNICH, R., 2012. Siedlce, s. 53-68. 
veřejnost jsou - s menšími omezeními - zpřístupněny rovněž převážná část knihovny a vzácný archiv Jednoty bratrské. Část sbírek knihovny a archivu je dnes $\mathrm{v}$ držení dalších institucí, především knihovny polské Akademie věd (Biblioteka Kórnicka), knihovny Biblioteka Raczyńskich, Státního archivu v Poznani (Archiwum Państwowe w Poznaniu) a lešenského muzea.

Byly napsány mnohé významné odborné práce věnované J. A. Komenskému a dějinám českých bratří - včetně těch, které se Komenského osobností zabývají z polské, či prrímo lešenské perspektivy. ${ }^{2} \mathrm{Na}$ druhou stranu je věnována jen malá pozornost dnešnímu pohledu na Komenského a významu odkazu českých bratří. Z tohoto důvodu se zaměřuje tento příspěvek na prezentaci nadčasové prrítomnosti Komenského v Lešně až po současnost.

Stavby připomínající Komenského zaujímají ve veřejném prostoru Lešna významné místo: kostel svatého Jana (postavený v letech 1652-1654), kde Komenský sloužil jako kněz, a dva Komenského pomníky. Autorem prvního z nich, který vznikl roku 1898 z veřejné sbírky, je Alfred Reichel. Pomník byl odhalen v den výročí Komenského příchodu do Lešna a dnes ho nalezneme na Komenského náměstí. Druhý pomník byl postaven roku 2003 před Státní vysokou odbornou školou, která nese Komenského jméno.

V 19. století začali Lešno navštěvovat čeští badatelé a duchovní, např. František Palacký či Jan Evangelista Purkyně. Hledali zde rukopisy Komenského a českých bratří. Jejich odkazu se už nějaký čas věnuje větší pozornost také v Lešně. Historické povědomí se promítlo mj. do tendence studovat minulost a pořádat vzpomínkové akce. Zvláštní význam měly tyto akce v kontextu lešenského gymnázia, které navázalo

2 Např́iklad KVACSALA, J., 1893. Des Komenský Aufenthalt in Lissa, Poznaň; DWORZACZKOWA, J., 2003. Czeskie początki Leszna. Mit czy rzeczywistość? In: Z dziejów braci czeskich w Polsce. Poznaň, s. 27-31; DWORZACZKOWA, J., 1992. „Czarna legenda” Komeńskiego a rzeczywistość historyczna. In:Jan Amos Komeński dziś i jutro. Lešno, s. 11-22.

3 BŁASZKOWSKI, M., 2012. Pomnik Jana Amosa Komeńskiego w Lesznie - kontekst historyczny powstania oraz dzieje. Rocznik Leszczyński. Č. 12, s. 53-71. 
na zvyklosti školy, kde dříve Komenský působil. První jubilejní akce zde byla uspořádána roku 1705, ale spojení s významným pedagogem bylo naplno artikulováno ažv 19. století. Olejomalba s portrétem Komenského vznikla roku 1835 a zahájila tradici galerie portrétů ředitelů gymnázia. Na Komenského odkazovaly rovněž další oslavy u příležitosti výročí školy a výročí Komenského narození a jeho příchodu do Lešna. Roku 1898, u příležitosti jubilea příchodu českých bratří do Lešna, získala škola Komenského jméno a před kostelem svatého Jana byl odhalen Komenského pomník. Oslavy výročí provázela velmi produktivní publikační činnost, která zahrnovala př́ležitostné texty, ale i historické studie o dějinách gymnázia, o faře svatého Jana a další specifická témata. Většina těchto iniciativ vzešla z okruhu učitelů školy a duchovních, kteří zde vyučovali náboženskou výchovu. ${ }^{4}$

Lešenské školy na některé $\mathrm{z}$ těchto aktivit dodnes navazují. Komenského jméno nese vedle již zmíněného náměstí a vysoké odborné školy ${ }^{5}$ také obchodní škola, která je partnerskou institucí gymnázia v Uherském Brodě. Na obchodní škole v sedmdesátých letech 20. století působilo studentské divadlo, uvádějící mj. Komenského hry. ${ }^{6}$ Každoročně se zde slaví patronovo výročí, nejinak je tomu od roku 2014 také na lešenské vysoké odborné škole.

\section{Na poli popularizace vědění a vědeckého výzkumu}

O vyhodnocení sbírky předmětů z odkazu českých bratří a Komenského se v19. a 20. století nejvíce zasloužil Wilhelm Bickerich (1867-1934),

4 Nejvýznamnější publikace: A. von Sanden, Zur dreihundertjährigen Jubelfeier der ehemaligen Schule, des nachherigen Gymnasiums der reformirten Brüder-Unität, jetzigen Königlichen Gymnasiums zu Lissa..., Lešno [1855]; Festrede zur 350jährigen Jubelfeier des Königlichen Komenský-Gymnasiums zu Lissa bei dem Festakt am 19. October 1905, Lešno 1905; A. von Sanden, Zur Geschichte der Lissaer Schule 1555-1905, Lešno 1905; MACHNIKOWSKI, S., 1937. Dzieje Gimnazjum Leszczyńskiego (1555-1920), Lešno.

5 Państwowa Wyższa Szkoła Zawodowa im. Jana Amosa Komeńskiego w Lesznie.

6 JĘDRAŚ, S., 1984. Wspótpraca Zespotu Szkót Ekonomicznych w Lesznie z gimnazjum w Uherskim Brodzie, Rocznik Leszczyński. 4, s. 372-377; Program sztuki: Opowieść o Herkulesie, 1970, Lešno. 
duchovní fary svatého Jana. Byl autorem mnoha studií a příspěvků o dějinách města, Jednotě bratrské a Komenském samotném. Rovněž zpřístupnil historické prameny veřejnosti. ${ }^{7}$ Po druhé světové válce se projevily intenzivní snahy o prezentování Komenského v kontextu jeho života a působení v Lešně. Tomuto účelu sloužily celostátní konference pořádané polskou Akademií věd a lokální organizacemi, jako jsou nap̌r. Kulturní spolek Lešno a v poslední doběi Státní vysoká škola s profesním zaměřením Lešno. Zmíněné konference se konaly v letech 1956, 1978, 1983, 1992, 2009 a 2010. Jejich výsledkem byly publikace, které prezentovaly cenné poznatky o dějinách Jednoty bratrské a osobnosti Komenského. Mezi autory př́spěvků byli zastoupeni významní vědci jako např. prof. Jolanta Dworzaczkowa z Univerzity Adama Mickiewicze v Poznani. Vedle publikování vědeckých výstupů se lokální badatelé věnovali rovněž př̀kladům. Díky tomu byly polským čtenářům zpř́ístupněny významné texty, jako např. Panegyricus, Lesnae excidium (Zničení Lešna) a dopisy, které napsal Komenský roku 1656 svému zeti Petru Figulovi. ${ }^{8}$

\section{Role Oblastního muzea v Lešně}

Oblastní muzeum v Lešně prezentuje osobnost Komenského ještě v dalším rozměru. Instituce nejenže dokumentuje cenný odkaz Komenského a českých bratří, ale rozvijí v tomto kontextu také mnohostrannou činnost, organizuje výstavy a vzdělávací aktivity a vydává publikace.

Ačkoli je Oblastní muzeum v Lešně institucí archivující sbírky z různých oblastí, věnuje zvláštní pozornost dějinám Jednoty bratrské, která se stala nedílnou součástí protestantského dědictví města a regionu.

7 Biografie In: Stownik biograficzny Leszna, 2008. Lešno, s. 41-43.

8 Sesja naukowa $w$ Lesznie $w$ czterechsetna rocznice powstania Gimnazjum i trzechsetna wydania „Opera didactica omnia” J. A. Komeńskiego (vyd. Ł. Kurdybacha, Vratislav 1957); Polsko-czeskie sympozjum komeniologów Leszno 27-28 maja 1978 (vyd. J. Głowinkowski, Lešno 1979); Jan Amos Komeński dziś i jutro, (vyd. A. Konior, Lešno 1992); Jan Amos Komeński i bracia czescy w 380 rocznicę przybycia do Leszna 1628-2008) (vyd. A. Konior, Lešno 2009). 
To je vynikající vizitka instituce, která může pyšnit tím, že má ve svých sbírkách unikátní náhrobní portréty aristokratických patronů Jednoty bratrské, cenné vybavení kostela a zajímavou sbírku knih. ${ }^{9}$ Sbírky jsou prezentovány $\mathrm{v}$ rámci dočasných výstav pořádaných muzeem, ale i v rámci výstavních projektů v dalších polských městech a v zahraničí. Objekty související s Jednotou bratrskou a Komenským jsou v budově muzea součástí stálé expozice, jež je věnovaná portrétnímu malířství a dějinám Lešna. V devadesátých letech 20. století došlo ke změně výstavní koncepce a bylo učiněno rozhodnutí, že budou zmíněné objekty místo zvláštní výstavy začleněny do expozice, která dokumentuje dějiny Lešna až do konce 18. století. Záměrem přitom bylo ukázat zmíněnou náboženskou obec a její zástupce v kontextu dění města, jehož byli součástí, v němž žili a pưsobili.

Vedle uměleckých předmětů neobyčejné hodnoty si v muzeu zvláštní pozornost zaslouží sbírka knih. Ta zahrnuje zajímavé a vzácné archivní materiály k dějinám Jednoty bratrské, ke Komenského osobnosti a dílu (včetně různých vydání) a k dalším autorům z okruhu českých bratří. Publikace, které jsou datovány od 17. století až po současnost, muzeum důsledně sbírá od svého založení v roce 1950. Ačkoli tento knižní fond tvoří jen zlomek bohaté sbírky k dějinám Lešna, je stále rozšiřován o knižní dary a nově zakoupené publikace. Za pozornost stojí kolekce děl vzniklých u př́ležitosti Komenského výročí v letech 1892 a 1898, dále pak knihy, které byly publikovány v Lešně v 19. století a v první polovině 20. století, a v neposlední ŕadě díla klasikư komeniologie (např. Johann Kvascala, Bernhard Czerwenka, Jaroslav Bidlo). Mimořádně významná jsou díla lokálních odborníků, jako byli Wilhelm Bickerich a Theodor Wotschke, kteří v 19. a 20. století čerpali z pramenů tehdy ještě dostupných v archivu a knihovně Jednoty bratrské. Vedle historického knižního fondu se muzeu daří průběžně aktualizovat sbírku

9 MICHALAK, G., 2002. Pamiątka wieczna nigdy nie ustaje... W kręgu leszczyńskiego portretu trumiennego, Lešno; SZYMAŃSKA, Kamila, 2007. Bracia czescy w Lesznie. Przewodnik po zbiorach Muzeum Okręgowego w Lesznie, Lešno; SZYMAŃSKA, Kamila, 2014. Losy księgozbiorów parafii ewangelickich w Lesznie. In: Dziedzictwo utracone - Dziedzictwo odzyskane. Vratislav: A. Kamler, D. Pietrzkiewicz, s. 201-221. 
aktuální komeniologické literatury, a to především díky časopisům Acta Comeniana a Studia comeniana et historica a současným badatelům (mj. Jolanta Dworzaczkowa, Marta Bečková, Markéta Klosová). Knihovna sbírá rovněž vydání Komenského děl z 19. a 20. století (kuriozitou, která rozhodně stojí za zmínku, je aktuální japonské vydání díla Orbis sensualium pictus). Sbírku využívají především studenti, vědečtí pracovníci a regionální badatelé.

V posledních letech se prohloubila spolupráce Oblastního muzea v Lešně s českými muzei v Přerově a Uherském Brodě, s Národním pedagogickým muzeem a s knihovnou J. A. Komenského v Praze. Tyto kontakty se promítly do výstav, jako je např. dočasná expozice Jan Amos Komenský a Polsko, připravená roku 2009 za využití jak exponátů vlastních, tak i zapůjčených z Polska a Čech (Muzeum v Přerově a Knihovna Univerzity Palackého v Olomouci). Mimořádně intenzivní a plodnou spolupráci muzeum navázalo s Národním pedagogickým muzeem a s knihovnou J. A. Komenského v Praze. ${ }^{10}$ Roku 2018 se v Oblastním muzeu v Lešně konala výstava Komenského fascinujicí Labyrint světa a ráj srdce v kolážích Miroslava Huptycha. Ke kolážím inspirovala umělce nejvíce překládaná kniha Komenského Labyrint světa a ráj srdce. Zmíněná výstava se konala v jubilejním roce prvního vydání Komenského knihy. Významnou součástí spolupráce je výměna zkušeností a stálý kontakt.

V minulém desetiletí zesílila publikační činnost a popularizace poznatků o komeniologické literatuře obsažené ve sbírkách muzea a o přítomnosti Komenského v Lešně. Spolupracovníci Oblastního muzea v Lešně se také účastní vědeckých konferencí. K nejvýznamnějším projektům na poli popularizace sbírek souvisejících s Jednotou bratrskou a Komenským patří publikace Čeští bratři v Lešně. Průvodce sbírkami Oblastního muzea v Lešně z roku 2007. Vedle seznamu nejvýznamnějších objektů $\mathrm{k}$ danému tématu obsahuje muzejní

10 Dokladem je skutečnost, že Oblastní muzeum v Lešně vydalo roku 2017 polský překlad publikace Markéty Pánkové Jan Amos Komenskýv nás. Citáty z dila Komenského jako životní inspirace, studie o něm a rodokmen Komenského. Kniha obsahuje reprodukce koláží Miroslava Huptycha a originálně ilustrovanou přílohu, která dokumentuje odkaz Komenského a Jednoty bratrské v Lešně. 
průvodce i výběr reprodukcí a doprovodný text o dějinách Jednoty bratrské v Lešně, o Komenském, př́íslušnících rodu Leszczyńských a významných členech Jednoty bratrské. V konferenčních sbornících byly publikovány příspěvky přednesené spolupracovníky Oblastního muzea v Lešně na konferencích v polském městě Siedlce. ${ }^{11}$

Muzeum vychází vstříc potřebám škol a dalších organizovaných skupin a nabízí bohatý vzdělávací program, který je zveřejňován na webové stránce muzea ${ }^{12}$. Vzdělávací programy („Reformace v Lešně“, „Jednota bratrská v Lešně“, „Jan Amos Komenský“, „Lešno - město mnoha vyznáni“), které jsou již několik let ve stálé nabídce muzea, př́imo souvisí s komeniologickou problematikou a s dějinami Jednoty bratrské. Každý program má formu přednášky, spojené s diskuzí a aktivní účastí návštěvníků (vyplňování pracovního listu, řešení křížovek, deskové hry či řešení úkolů během prohlídky). Otázky ke Komenskému a Jednotě bratrské se pokládají také na př́ležitostných nebo pravidelných přednáškách pro studenty univerzity třetího věku, s níž muzeum spolupracuje již přes 10 let. U př́ležitosti každoroční Muzejní noci mají návštěvníci muzea př́ležitost seznámit se atraktivní formou s exponáty, které se vystavují jen zřídka, jako např. exempláře Orbis sensualium pictus, nebo vyslechnout přednášky věnované významným osobnostem Jednoty bratrské. Atraktivní a oblíbená forma dalšího vzdělávání jsou procházky městem, které mj. zahrnují návštěvu kostelů, lapidária s náhrobními sochami z evangelických hřbitovů zrušených

11 ŚLIWIŃSKI, E. Schule in Leszno in der ersten Hälfte des 17. Jahrhunderts; SZYMAŃSKA, Kamila. Leszno im 17. Jahrhundert und seine Verbindungen mit der europäischen Kultur, Jan Amos Komenský und die Brüder-Unität in den Kollektionen des Regionalmuseums in Leszno und Rezeption von Jan Amos Komenský in Leszno bis 1939 auf dem Hintergrund des Interesses in Mitteleuropa am Pädagogen und seinem Werk - sv. IV. Kromě toho byly v časopise Siedleckie Zeszyty Komeniologiczne uveřejněny následující články: Komenský in Leszno (sv. 1., 2014, s. 301-308), Das Schulwesen in Leszno zur Zeit Komenský (sv. 1., 2014, s. 309-312), Ausländische Kontakte von Jan Amos Komenský (Abriss der Problematik) (sv. 2., 2015, s. 227-235), Archiv Jednoty bratrské in den Sammlungen des Staatlichen Archivs in Poznan. Geschichte - Inhalt - Bedeutung für die comeniologische Forschung (sv. 3., 2016, s. 115-121).

Více viz www.muzeum.leszno.pl (v rubrice Edukacja). 
po druhé světové válce a dalších staveb souvisejících s daným tématem. Tyto procházky se pořádají každoročně v letních měsících a přitahují i zájemce ze zahraničí. Vzdělávací aktivity jsou určeny všem věkovým skupinám, včetně nejmladších návštěvníků. V roce 2017 proběhly oslavy 325. výročí Komenského narození. V březnu u této př́ležitosti nabídlo muzeum zvláštní program. Nejmladší návštěvníci se mohli po celý rok účastnit uměleckých workshopů v duchu Učitele národů. Atrakce, která oslovila všechny návštěvníky bez rozdílu věku, byla atrapa s reprodukcí Komenského portrétu, se kterou se bylo možné vyfotografovat. Tento nápad přesahoval princip hry, v němž se celý program nesl, a měl fixovat adekvátní asociace a vztahy: Lešno - Komenský. Aktivity, které zahrnovaly rovněž oslavu Komenského narozenin pro děti, navíc odpovídaly aktuálnímu muzeologickému trendu, podle kterého může být muzeum také místem zábavy.

Dočasné výstavy jsou vždy provázeny zvláštním vzdělávacím programem, který je upravený na míru danému kulturnímu kontextu. Zvláštní prŕležitost poznat osobnost Komenského nabídla výstava Hlavní města protestantství ve Velkopolsku. Lešno a Śmigiel - koexistence náboženství, která se konala do konce roku 2017 a kterou provázel vzdělávací program určený různým věkovým skupinám, zahrnující přednášky, programy a workshopy. Některé dočasné výstavy představily Komenského z různých úhlů pohledu, další pak jej nastínily jako osobu účastnící se událostí, jimž byla daná výstava věnována. Pestrá tematika výstav umožnila prezentovat Komenského jako pastora u svatého Jana, pedagoga lešenského gymnázia, autora panegyriky věnované Karlu Gustavovi, jako vyjednavače na Colloquium charitativum, jako aktivního účastníka rozhovorů s přívrženci socianismu i jako šiřitele kontroverzních prorockých vizí Krystyny Poniatowské, Mikuláše Drabíka a Kryštofa Kottera. ${ }^{13}$

13 Stolice wielkopolskiego protestantyzmu. Leszno i Śmigiel-wspótistnienie wyznań. Dziedzictwo, 2018. Lešno: K. Szymańska. 